E Q U I L I B R I U M

Volume 6 IsSue 3, 2011

IS S N $1689-765 \mathrm{X}$

Liana Badea
Academy of Economic Studies from Bucharest, Romania

\title{
Economic Crisis and Education. Case Study: THE Romanian Educational System*
}

JEL Classification Codes: $A 20$, I00

Keywords: education, crisis, universities, ethics

\begin{abstract}
Over the years scholars, politicians, economists and others have recognized that no country could achieve economic growth and development without an efficient educational system. Functional education plays a central role in preparing individuals to become the labour force and in the same time to respect the environment in order to use efficiently the resources. It is said that from immemorial times, education was the one who offered solutions to various problems, but also generated a lot of controversies in the evolution of the world. Thus, in the case of a crisis, the education must be studied from at least two points of view. When speaking about crisis, first we must pose a question whether education is only a victim of the crisis or it may be a cause or a part of the solution needed to exit from the crisis. Starting from such a question, this paper aims to emphasize the existing connection between economic crisis and the contemporary education. The paper starts by using a retrospective and contrastive analysis, based on methodological pillars such as: filiations of ideas, genesis, and statistics. Using quantitative and also qualitative methods, the paper focuses on the way of functioning of the Romanian educational system and offers suggestions how to improve it.
\end{abstract}

\section{Introduction}

At present, many economists speak about causes and effects of the economic crisis, asking themselves whether they should emphasize the education as a cause or as a solution of it. The whole situation at the global level seems to be recover-

* This work was cofinanced from the European Social Fund through Sectoral Operational Programme Human Resources Development 2007-2013, project number POSDRU/89/1.5/ S/59184 „Performance and excellence in postdoctoral research in Romanian economics science domain". 
ing after the crisis; in the early 2011, about two and a half years after the global financial crisis broke, economic output in the EU10 returned to the pre-crisis level (World Bank 2011, p. 2). Helped by aligned business cycles and close trade and production linkages, economic activity in the EU10 rebounded in parallel with the EU15 (World Bank 2011, p. 2). But, there are still countries that try to recover adopting different measures.

In this context, one must see that the bailouts from rich countries and the International Monetary Fund still require austerity measures that are affecting wages, jobs and educational programs in the receiving countries. In addition, the high-debt countries are losing political and economic sovereignty to international organizations. The obvious example is Greece; however, many Eastern European countries have also had to take this route and have been heavily influenced.

Recent concerns about the sustainability of sovereign debt in Europe, and the stability and efficient functioning of financial markets more generally, have contributed to the list of concerns. The present situation emphasizes the importance of mapping out clear exit strategies to get economies back on a steady footing. Following the Europe 2020 strategy, EU member states are preparing their national reform programs with specific-country targets. These strategies will build on lessons from government policies during the crisis. According to the World Bank, the recovery of our country (Romania) is going to be seen in 2011 and in 2012, the projected GDP growth, reaching $1.5 \%$ in 2011 and $4.4 \%$ in 2012 (World Bank 2011, p. 2).

Policymakers are struggling with ways of managing the present economic challenges while preparing their economies to perform well in a future economic landscape characterized by uncertainty and shifting balances (Sala-I-Martin et al. 2010).

Every time a crisis such as the current one happens, the instability of the markets, the destruction of wealth, the unfortunate but all too real cases of fraud, abuse and perceived unfairness in organizations seriously undermine the morale of employees, shareholders and investors and their confidence in markets and business firms (Patry 2010). And confidence in economic schools is eroded too, not surprisingly. Hence, one major task that confronts even economic schools today consists of weaving the building of trust into economic education.

Unfortunately, in many countries, the crisis hit the educational sector. Some say that the public sector is now being called upon to pay for a disaster inflicted on us all by private sector greed (Bennett 2010, p.1). In this context, in many countries governments have implemented budget cuts. This measure was taken in Romania, too, which has seen a 25 percent cut on already low salaries. In this circumstances, the government had to see that higher education and research are part of the solution: everyone can see the logic of investing in higher education and research at a time of recession, but in the longer term the universities may provide solutions to the big scientific, technological and social problems (Bennett 2010, p. 1) - many 
of them seemingly intractable - which confront the global polity. Certainly that makes more sense than the slash-and-burn that many countries are facing, or the discredited panaceas restructuring higher education as private profit centres.

The current crisis cannot altogether mask the underlying seismic shift towards a more globalised higher education and research community, an arena in which models of cooperation and collegiality versus competition and corporatism, vie for hegemony (Bennett 2010, p.1).

In such a context, we must see the importance of the higher education system, which has to be developed, not destroyed. In such a global economic environment, it is more important than ever for countries to put into place the fundamentals underpinning economic growth and development.

\section{Higher education system}

Education worked in society as a function depending on the characteristics of the environment in which man lived and adapted to the social requirements. Education and instruction have been generated among others by the need to administer the individual and public property.

The fact is that education itself is a major factor when talking about the past of the society, but especially when we think about its future.

Thus, authors like John Kenneth Galbraith tried to show that our evolution as individuals and as a society is inextricably linked with education: The main factor of evolution, as individual, or as its children on the social scale is represented by education. Ignorance leads only to hard work, uncomfortable, boring and often, to not work at all. The improvement comes once with education and only with it; there is nothing without education and the only plausible last appeal is to crime and violence. It may be possible that people on the lower social level get the best education, as they are in great need of means to allow them to climb, to get rid of ignorance (Galbraith 1997, p. 67).

In the past few years, a paradigm shift occurred: while the old approaches (such as utilitarianism) concerned with the availability and 'the quantity' of education, the modern ones (such as capabilities approach) are more oriented towards the nature and quality of education. As Parfit argues If two communities spend equal amounts on television, but one broadcasts rubbish, the value of having television may be, for those in the second community, less. And, if two communities spend as much on education, but one has much worse educated children, the value of their education may be less (Parfit 1993). Therefore, it is obvious that education plays an active role in designing the society and that the way it is directed affects the future of nowadays generations.

Currently, however, academicians believe that educational market begins to face a very difficult situation. Globally, they are speaking about the economic 
crisis and the causes, respectively its effects. What usually is not emphasized is that we cannot address the economic crisis without being concerned about the progress and quality of education. The academician Mircea Malița said that unlike the economic crises that periodically erupt in acute or moderate forms, the global education system seems to be in a continuous crisis, chronic, slow and persistent, which has not yet found its cure. Universities, which are the crown of the educational systems, at the end of cycles, totalling up to two decades of life, are always a subject of critical observations resulting from the economy and made by the representatives of the public administration, by politicians, by the ones coming from the industry and are always confronted with the growing demands of the old professionals, and especially of those that currently appear (Malița, Georgescu 2010, p. 275).

Contemporary economists are beginning to wonder when talking about the cause or causes of the crisis whether we must search for them among the others or inside of us. Is there the economic science the guilty one for our brief and incomplete knowledge? Do we face an unprecedented crisis, with a far future, 'infecting' our economic way of thinking? Is there the economic thinking in crisis or are we running out of ideas? On such a type of questions those concerned with the development of our present society should answer in order to be able to go further.

Increasingly more often at the academic level, there are discussions about the indissoluble link that exists between the education in general, and higher education, in particular and prosperity or economic development or quality of life etc.

Analysing the higher education, H.R. Bowen showed that: The primary purpose of higher education is changing people in the wanted ways. In their turn, these changes can have profound effects on the economy and society and even on history. But in the first instance, the objective is to modify the qualities and behaviours of human beings (Bowen 1977).

The experts stress the importance of the fact that education has been achieving a higher level of living. Currently, in our country the analysis of the educational system and of its implications on the economy shows that the travelled road was long and difficult and, unfortunately, it still requires overcoming some significant obstacles.

\section{An overview of the Romanian higher education system}

\section{A brief history}

Romania is one of the former socialist countries that is still experiencing serious problems in its efforts to complete economic and social reconstruc- 
tion. Despite many difficulties, important changes have taken place and progress has occurred in the building of democratic institutions and the setting up of a market economy.

Romania has inherited from the communist regime a system with high standards (stringent entrance examinations to the most coveted high schools and universities), a massive participation (albeit decreasing) and a considerable stress on science and technology, but also characterized by a lack of flexibility (SAR 2007, p. 5).

At present, the Romanian higher education system is very homogeneous. Higher education in Romania is offered in both public and private higher education institutions.

All higher education institutions are coordinated/report to the Ministry of Education and Research. Under the authority of the ministry there are agencies that play a very important role in fields such as financing and scientific research or partnerships with social and economic environment.

Private universities occupy a special niche in Romanian higher education. Before 1990, there were no private higher education institutions. The first one emerged in 1990. Some of them were created as foundations, i.e., non-profit organizations.

But others were created as for-profit companies, owing to expected changes in legislation and taking advantage of the fact that, at that very moment, there was no law stating what the necessary conditions were for any institution to declare itself a university.

When the new Constitution of Romania appeared in 1991, it recognized the possibility of the creation and the functioning of private education institutions at any level.

It is not to be neglected that in Romania, starting with 1990, the higher education has experienced an intense process of massification.

Thus, over time the number of students and graduates of higher education has significantly increased compared with the characteristic level of the years before 1990. The chart below shows that the trend of higher education graduates was preserved.

According to the data presented above, the interest has slightly shifted from technical specializations toward social sciences and humanities. This result is consistent with the structural changes occurring in Romanian economics where in 2009 share of services in GDP exceeded, for the first time, the threshold of fifty percent. In the same time, we can observe a significant increase in total number of students weighted to population due, on one hand, to the increasing number of students and, on the other hand, to a significant decrease in population. 
Figure 1. Students in higher education institutes, by specialization groups
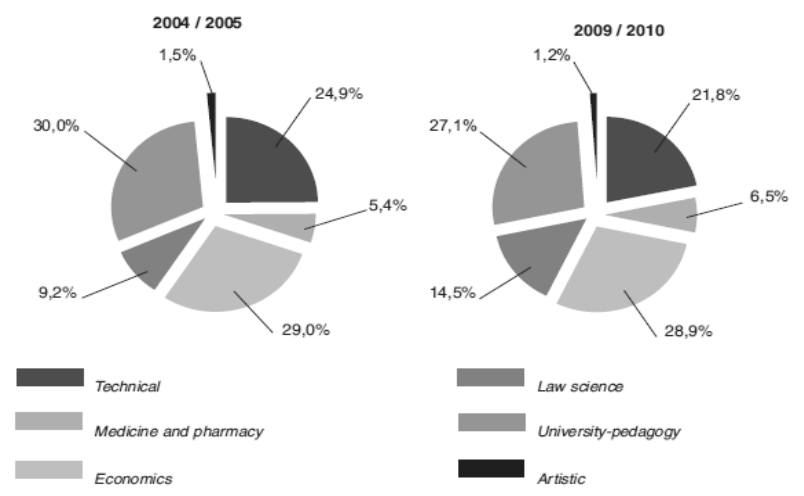

Source: National Statistical Institute of Romania (2010, p. 244).

Figure 2. Evolution of student/population ratio and of graduates/population ratio

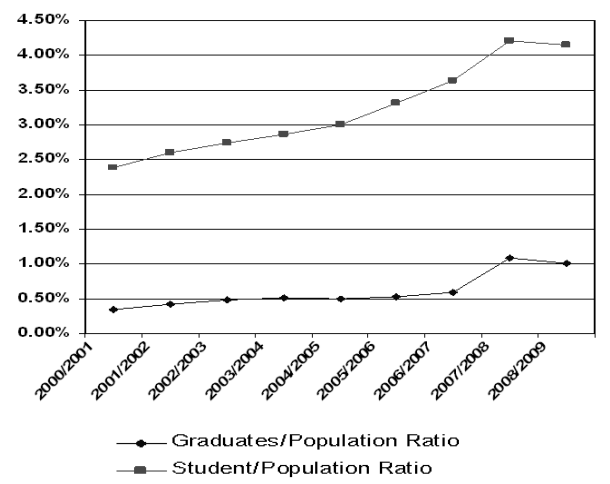

Source: author's work using data from National Statistical Institute of Romania (2010).

Today, we see that in order to align the Romanian education system to those existing in the EU, Romania started to implement the Bologna process; in this regard the tertiary educational system of Romania receives positive reviews and has a good image.

According to the Bologna Process Stocktaking Report (prepared for the Ministerial Conference in Leuven 2009), our country has received the rate 'excellent performance' for 8 of the 12 indicators that measure the degree of the implementation of the Bologna Process (ARACIS 2009). Thus, there were highly rated the international ARACIS evaluation and the receiving by the Romanian agency of the full membership in the European Association for Quality Assurance in Higher Education (ENQA) and particularly in the European Quality Assurance Register (EQAR) (ARACIS 2009). But, the economic problems of recent years led to the under-funding of the education sector; hence, the insufficient resources 
directed at teacher training. Similarly to the other sectors, education has been and still is subject to important and diverse changes.

The public-private partnership in education still remains an exception. The investment in the research and development area remains inadequate, as show the majority of the reports conducted at European or at global level.

As far as the access to education is concerned, it ranks around the international average in Romania. Enrolment rates at primary and secondary level place the country as 51st and 53rd in the Index, respectively, and there is gender equality in primary and secondary education. There is a high ratio of 17 primary pupils per teacher in classroom (Legatum Institute 2010). Access to tertiary education is somewhat better, placing the country as 31 st overall. Still, Romanians are relatively dissatisfied with the education available, taking the 69th place in this respect. Moreover, the proportion of Romanians who feel that children have the opportunity to learn and grow every day is below the international average, placing the country 74 th, overall. The Romanian workforce has solid basic education, with an average of 3.3 years of secondary schooling each, but little specialised knowledge, with just 0.8 years of tertiary education on average (Legatum Institute 2010).

Regarding the lifelong learning, Romania also has some obstacles to overcome, as the overall results for the European Lifelong Learning Index show that the lowest performing group of countries is comprised of Southern and Eastern European countries, including Hungary, Greece, Bulgaria and Romania, while the Nordic countries Denmark, Sweden and Finland and, in addition, the Netherlands rank highest. The Nordic countries are followed by a group of countries that consist of mainly Central European and Anglo-Saxon countries. The next group of countries, which are below the EU average, are from Southern and Eastern Europe and range from the Czech Republic to Poland (ELLI 2010).

Education is not a one-time event. Life-long learning is a necessity in today's rapidly changing world. That means providing students with both the desire and the tools to continue their education.

The image that Romania has at European level in terms of formal implementation of the Bologna principles is not exclusively positive.

\section{Problems of the higher education system in Romania}

Among the problems of the Romanian higher education system one may include the corruption. When speaking about corruption and education, we must follow two approaches: 1) educational system may be a sector with corruption and 2) education may be a very important tool in fighting the corruption problem as it creates a certain way of thinking.

According to the Global Corruption Barometer 2010, the education system seems to be one of the sectors affected seriously by corruption. That is why, in 
the whole world, it is necessary to take some measures in order to diminish and eradicate this phenomenon.

It is well known that corruption in education has severe consequences, such as:

- A high drop-out rate, which increases at high levels of poverty,

- Low quality teaching, leading to poor achievement,

- A system susceptible to adverse political, religious and ethnic influence,

- Deepened inequality between rich and poor, preventing entire generations from pursuing a meaningful future,

- Creates an unhealthy mentality according to which it is a normal thing to bribe and not to respect the law,

In every educational institution, in every country and generation, there is a struggle between corrupt practices and the continuing quest for high ethical standards.

Corruption is very likely to occur where teachers receive little or no payment (like in Romania), where officials exercise financial discretion and power over the public, and where the risk of detection and severe punishment is low (Rogojanu, Badea 2011, p. 4).

The situation in the Romanian education sector has gone through a difficult period. The importance of adequate remuneration to ensure an honest civil service is widely recognised in the international discourse on civil service and pay reform.

Starting from such aspects, one must realise that corruption is like a disease spreading in the whole organism of the national economy.

Besides the corruption, the system is facing a lot of other problems such as:

- delays in implementing the national framework of qualifications in higher education; this problem is not only the one of Romania, it is somewhat general in Europe;

- a low rate of participation in training programs and professional development of employees, Romania being next to Bulgaria in the European rankings (1.3\% versus $29.2 \%$ - Denmark, the highest recorded in Europe);

- This is hardly encouraging, given the fact that in Romania the rate of professional employability of the population between 15-64 years was $59 \%$ in 2008 compared to the EU27 average of $65.9 \%$ (ARACIS 2009: pp. 6-10);

- a gap between the external national system of quality assurance, positively evaluated at the European level and the ability of universities to implement the mechanisms of providing and improving the quality in education. According ARACIS many of the Romanian universities do not have active committees for internal quality assurance and face difficulties in providing data and information for the quality certification;

- underdeveloped systems for advice and career guidance, as well as employment of students; 


\section{Table 1. Corruption in education - some forms}

\begin{tabular}{|c|c|c|}
\hline Corruption & Corruption & Corruption \\
\hline $\begin{array}{l}\text { - Illegal charges levied on } \\
\text { children's school admis- } \\
\text { sion forms which are } \\
\text { supposed to be free; } \\
\text { - School places 'auctioned' } \\
\text { out to the highest bidder; } \\
\text { - Children from certain } \\
\text { communities favoured for } \\
\text { admission, while others } \\
\text { are subjected to extra } \\
\text { payments; } \\
\text { - Good grades and exam } \\
\text { passes obtained through } \\
\text { bribes to teachers and } \\
\text { public officials. The prices } \\
\text { are often well known, and } \\
\text { candidates can be expected } \\
\text { to pay upfront. } \\
\text { - Staff exploiting and } \\
\text { abusing pupils in many } \\
\text { different ways (physically, } \\
\text { sexually, etc.). } \\
\text { - Teacher recruitment and } \\
\text { postings influenced by } \\
\text { bribes or sexual favours. } \\
\text { - Exam questions sold in } \\
\text { advance. } \\
\text { - Examination results only } \\
\text { released upon payment; } \\
\text { - Sub-standard educational } \\
\text { material purchased due } \\
\text { to manufacturers' bribes, } \\
\text { instructors' copyrights, etc. }\end{array}$ & $\begin{array}{l}\text { - Schools monopolising me- } \\
\text { als and uniforms, resulting } \\
\text { in low quality and high } \\
\text { prices. } \\
\text { - Private tutoring outside } \\
\text { school hours given to } \\
\text { paying pupils, reducing } \\
\text { teachers' motivation in } \\
\text { ordinary classes, and rese- } \\
\text { rving compulsory topics } \\
\text { for the private sessions } \\
\text { to the detriment of pupils } \\
\text { who do not or cannot pay. } \\
\text { - School property used } \\
\text { for private commercial } \\
\text { purposes. } \\
\text { - Pupils carrying out unpaid } \\
\text { labour for the benefit of } \\
\text { the staff. } \\
\text { - High absenteeism, with } \\
\text { severe effects on de facto } \\
\text { student-teacher ratios. } \\
\text { - Licences and authorisa- } \\
\text { tions for teaching obtained } \\
\text { on false grounds via } \\
\text { corrupt means. } \\
\text { - Ghost teachers' - salaries } \\
\text { drawn for staff who are no } \\
\text { longer (or never were) em- } \\
\text { ployed for various reasons } \\
\text { (including having passed } \\
\text { away). } \\
\text { - This affects de facto } \\
\text { student-teacher ratios, and } \\
\text { prevents unemployed te- } \\
\text { achers from taking vacant } \\
\text { positions. }\end{array}$ & $\begin{array}{l}\text { - Inflated student numbers } \\
\text { (including numbers of spe- } \\
\text { cial-needs pupils) quoted } \\
\text { to obtain better funding. } \\
\text { - Bribes to auditors for not } \\
\text { disclosing the misuse of } \\
\text { funds. } \\
\text { - Embezzlement of funds } \\
\text { raised by local NGOs and } \\
\text { parents' organisations. } \\
\text { - Politicians allocating reso- } \\
\text { urces to particular schools } \\
\text { to gain support, especially } \\
\text { during election times. } \\
\text { - Removing the consequ- } \\
\text { ences of failing exams } \\
\text { by (re)admitting students } \\
\text { under false names; } \\
\text { Embezzlement of funds } \\
\text { intended for teaching ma- } \\
\text { terials, school buildings, } \\
\text { etc. }\end{array}$ \\
\hline
\end{tabular}

Source: own work.

- alignment to the trends reported at the European and global level concerning the population ageing, and the population's demographic decline;

- reduced funding, compared with the EU Member States;

- a low standard of living, which can be an obstacle in access to a higher education;

- poor, inaccurate, incomplete and changing law in the field of education;

- growing gap between the public and the private higher education system, manifested even by differences in the quality; 
- plagiarism in academia;

- ability to meet the criteria considered by the international bodies to highlight the quality and quantity of scientific research;

- transparency and fairness of academia administration;

- etc.

Starting from just a few of the problems that our system is facing, one can easily understand why the Romanian universities do not occupy the leading places in international rankings.

\section{Crisis and education - a bidirectional connection?}

Nowadays, we can see that the quality of higher education and training is crucial for economies which want to move up in the value chain beyond simple production processes and products.

In particular, today's globalizing economy requires countries to nurture pools of well-educated workers who are able to adapt rapidly to their changing environment and the evolving needs of the production system. Today's world asks to train the people who are able to give practical solutions for economic problems.

Thus, we ask ourselves: is the educational system ready to provide such a thing? Is it enough to teach students how to memorize a bunch of theories? Is it enough to tell them which are the economic variables and how they evolve?

That is why it is particularly important to examine how research can energize and re-engage the brain and the voice of business schools in achieving a more effective strategic positioning in the context of the modern university.

The European Commission highlights the role of universities and of science and technology graduates in creating the necessary innovation for continued economic success.

In addition, education is also considered to be the policy tool for social inclusion, since the skills which individuals develop allow them to participate meaningfully in economic and social discourse.

EU 2020 proposes a benchmark for social inclusion in education and training, establishing that less than $10 \%$ of students should fail to complete their education and that at least $40 \%$ of the younger generation should obtain a degree or diploma (ELLI 2010).

However, in order to see which solutions are to improve the educational system, it is necessary to analyze what the claim about them. The focus is on the economic education. 
Figure 3. Criticisms directed at economic education

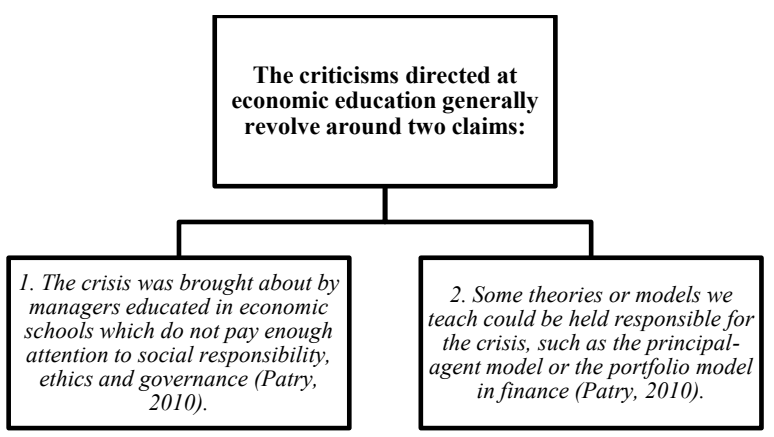

Source: own work.

What is worth emphasizing here is the importance of teaching economic doctrines or history of economic thought in economic schools and not only there, as it is necessary to know what happened in the past and how ideologies were related to economic variables in order to be able to make the right decision as an economist. Great economists of all times were preoccupied with studying the history of economic thinking first and then making economic decisions.

With regard to the first claim of the critics of economic education - unethical behaviour of some managers - we can see that today's managers are not, on the whole, more greedy or narrow-minded than their predecessors because of what they learned in business schools (Patry 2010). We can find no evidence to support this view there, but think of the landowners in ancient Rome, of the bankers and traders in medieval times, and of the industrial barons of the nineteenth century.

Consequently, if we are to understand human behaviour and influence it, we must recognize self-interest and, unfortunately at times, greed and opportunism. Economists and not only them should be asked and strongly encouraged to conform to the highest ethical standards.

Regarding the second claim, it is obvious that the critics question theorizing that occurs in business schools. Are the models and representations that we find in business education adequate or lacking? It is a well-known fact that all models are essentially lacking and imperfect, as nothing in this world is perfect (Patry 2010). We also know that a theory is not rejected because it is faulty; it is rejected when a better one is developed. Thus, we can find one more reason to emphasize the need to introduce into the curricula of all the economic schools subjects such as history of economic thought, economic doctrines, business ethics and epistemology.

Starting from the fact that usually a crisis brings some changes in business schools reflecting this historical economic collapse, we must see it as a window 
of opportunity for business schools to contribute to the development of better organizations and institutions, and thus to serve the society. Furthermore, universities might play a role in restoring the confidence of the public in business in general, in the efficiency of market economies, as well as the confidence of employees in the organizations that hire them - but this is far from certain.

There will be a vast amount of research devoted to diagnosing in great detail what has happened. Future dissertations will include questions of diagnosis and prognosis. Moreover, economic schools may be actually part of the solution for future crisis. Research may help explain and prevent future global economic meltdowns (Patry 2010).

The educational system is the one who can change mentalities and seed moral values. Investing in education is like investing in the future of society.

At the same time, one must realize the impact of crisis on education:

- in order to save some money, governments have reduced education expenditure, including higher education (Croatia (9\%), Czech Republic (5\% in 2010), Estonia, Hungary (10\%), Latvia, Lithuania (higher education not mentioned), Romania, Serbia (25\%), Slovakia) (De Koning 2010, p.11);

- cuts in salaries: between $3 \%$ and $25 \%$ at all levels;

- teachers have been laid-off because of crisis;

- schools, in particular small public schools in rural areas, were closed, merged, or reorganised (Latvia, Lithuania, Romania and Russia);

- class sizes expanded (Lithuania, Estonia) (De Koning 2010, p.11);

- increased hiring of unqualified teachers;

- curricula reduced: foreign language classes (Cyprus, Ireland \& Poland) $\&$ guidance counselling (Sweden, Spain) (De Koning 2010, p.17);

- rise in tuition fees or voluntary contributions;

- etc.

Economic impacts are felt around the world whenever a major economy experiences challenges (Patry 2010). It is also clear that developing economies need the attention and expertise from economic school educators.

\section{Conclusions}

Today, as in the past, we need to be forward-looking to adapt our educational system to the evolving needs of the economy and our changing society. We must work to provide graduates with the education needed to meet the realities of today's and tomorrow's market (Plosser 2008).

Those efforts will require the collaboration of policymakers and educators. However, if such efforts are successful, we can ensure a more productive, highly-skilled, technically trained workforce which will support a vibrant and robust economy in our region and the nation. The responsibility does not rest 
solely on the government and policymakers, who clearly must do their part. It rests mostly on individuals taking the responsibility to engage in life-long learning, making investments which will reward them handsomely.

Starting from the importance it has for the future of the society, the education may be seen as a goal, but also as a way towards finding the right solution in order to survive the current situation. It is of a great importance that education is one direct factor which influences the prosperity of a country. However, there remains an open question for academics and not only them: Is there any possibility to have an efficient and, thus, functional education system in the situation when teachers are poorly paid? Is there actually a crisis of the system or is it a crisis of ideas? Is there any possibility to create a system which is capable of realising a permanent connexion between the labour market and the educational one? Do we have the strength to create such a system which educates people and not clerks?

There are a lot of questions to be answered and this questions aim to formulate some problems in order to point that the crisis is a complex phenomenon and that overcoming it takes a lot of patience, courage and rationality in applying the right methods at the right time.

\section{Literature}

ARACIS (2009), Distribuții statistice, interpretări şi opțiuni privind Starea Calității în Învățământul Superior, Barometrul calităii, Bucharest, Romania.

Bennett P. (2010), General Report "The Vandals are at the gates": defending higher education and research in a time of crisis, United Kingdom, available at: http://download.ei-ie.org/ SiteDirectory/herg/Documents/2010_7thIHERC_Vancouver_FinalReport_en.pdf.

Bowen H. R. (1977), Investment in Learning: The Individual and Social Value of American Higher Education, Jossey-Bass, San Francisco, California.

De Koning M. (2010), Impact of the crisis on education. Findings from EI membership surveys, EUNEC Seminar Education and Training in Period of Economic crisis, Limassol, Cyprus, available at: www.ei-ie.org.

Galbraith J.K. (1997), Societatea perfectă. La ordinea zilei: binele omului, Eurosong Publishing House, Bucharest, Romania.

European Lifelong Learning Indicators (ELLI). Making Lifelong Learning Tangible!, Bertelsmann Stiftung, 2010. Available at www.elli.org.

Legatum Institute (2010), The Legatum Prosperity Index Report.2010, London, UK. Available at www.prosperity.com.

Malia M. and Georgescu C. (coord.)(2010), România după criză. Reprofesionalizarea, Publishing House Compania, Bucharest, Romania.

National Statistical Institute of Romania (2010), Statistical Year Book of Romania 2010, www. insse.ro.

Parfit D. (1993), Paul Seabright: Pluralism and the Standard of Livin, [in:] Martha Nussbaum and Amartya Sen (editors), The Quality of Life (Wider Studies in Development Economics), Oxford University Press, pp. 409-416. 
Patry, M. (2010), Economic Crisis: An Institutional Perspective, in From Challenge to Change: Business Schools in the Wake of Financial Crisis, Global Foundation for Management Education. Available at www.gfme.org.

Plosser C.I. (2008), Education and Economic Prosperity, Montgomery County Community College, Distinguished Lecture Series, Available at http://www.philadelphiafed.org/ publications/speeches/plosser/2008/04-16-08_montco-college.cfm.

Rogojanu A., Badea L. (2011), Corruption and education. How to achieve sustainable development?, „Supplement of Quality - Access to Success Journal”, Year 12, No. 121, Romania.

Sala-I-Martin X., Blanke J., Drzeniek Hanouz M., Geiger T., Mia I. (2010), The Global Competitiveness Index 2010-2011: Looking Beyond the Global Economic Crisis, [in:] The Global Competitiveness Index 2010-2011, World Economic Forum, Geneva.

SAR (2007), Lisabona, Bologna şi fabrica autohtonă de mediocritate, www.sar.org.ro.

World Bank (2011), EU10 Regular Economic Report. Main Report-Recovery and Beyond. Focus Notes: Fuelling Growth and Competitiveness through Employment, Skills, and Innovation. Household and Government Responses to the Global Financial Crisis, Available at:http://siteresources.worldbank.org/ECAEXT/Resources/258598-1303157205578/ EU10_RER_20April2012_Final.pdf. 